\title{
Chemopreventive Action of Garcinia Mangostana Linn. on Hepatic Carcinoma by Modulating Ornithine Decarboxylase Activity
}

\author{
Vishnu Priya Veeraraghavan ${ }^{1, *}$, Sardar Hussain², Janardhana Papayya Balakrishna ${ }^{3}$, Gayathri Rengasamy4, \\ Surapaneni Krishna Mohan ${ }^{5}$
}

Vishnu Priya Veeraraghavan ${ }^{1, *}$, Sardar Hussain², Janardhana Papayya Balakrishna ${ }^{3}$, Gayathri Rengasamy ${ }^{4}$, Surapaneni Krishna Mohan $^{5}$

'Department of Biochemistry, Saveetha Dental College, Saveetha Institute of Medical and Technical Sciences, Saveetha University, Chennai - 600077 , INDIA.

${ }^{2}$ Department of Biotechnology, Government science College, chitradurga-577501, Karnataka, INDIA.

${ }^{3}$ Department of Stem Cell Biology, Stellixir Biotech Pvt Ltd, No.V-31, 2nd floor, 10th Main Road, Peenya 2nd Stage Industrial Area,

Bangalore - 560058, Karnataka, INDIA.

${ }^{4}$ Department of Biochemistry, Saveetha

Dental College, Saveetha Institute of Medical and Technical Sciences, Saveetha University,

Chennai - 600077 , INDIA.

${ }^{5}$ Department of Biochemistry, Panimalar Medical College Hospital \& Research Institute Varadharajapuram, Poonamallee, Chennai 600 123, Tamil Nadu, INDIA.

\section{Correspondence}

\section{Vishnu Priya Veeraraghavan}

Department of Biochemistry, Saveetha Dental College, Saveetha Institute of Medical and Technical Sciences, Saveetha University, Chennai - 600 077, INDIA.

E-mail: drvishnupriyav@gmail.com

History

- Submission Date: 25-05-2020.

- Review completed: 22-07-2020;

- Accepted Date: 03-08-2020

DOI : 10.5530/pj.2020.12.191

Article Available online

http://www.phcogj.com/v12/i6

\section{Copyright}

(C) 2020 Phcogj.Com. This is an openaccess article distributed under the terms of the Creative Commons Attribution 4.0 International license.

\begin{abstract}
Ornithine decarboxylase and alpha -L- fucosidase over-expression is associated with advanced hepatocellular carcinoma (HCC) development. The objective of this study was to elucidate the action of Garcinia Mangostana fruit extract (GME) on these overexpressed enzymes and apoptotic proteins in diethyl nitrosamine (DEN) induced hepatocellular carcinoma (HCC) rats. The cancer was induced using DEN to the experimental rats and treated with GME $(400 \mathrm{mg} /$ $\mathrm{kg}$ ) to find its anticancer property. The lysosomal enzymes such as alpha-L-fucosidase, betaD-glucosidase, ornithine decarboxylase activity (ODC), apoptotic and antiapoptotic proteins such as Bcl-2, Bax and Bcl-xl and $\mathrm{H}^{3}$ thymidine incorporation assay were done to prove GME's chemo preventive property. DEN induction caused significant increase in the activities of ornithine decarboxylase; lysosomal enzymes and increased cell proliferation with decreased apoptosis were observed. In contrast, the groups with GME treated rat's elicited significant $(P<0.001)$ reduction in ornithine decarboxylase, lysosomal enzymes, and decreased cell proliferation with increased apoptosis. GME has effective chemo preventive property and can serve as an anticarcinogenic therapeutic drug against hepatocellular carcinoma.

Key words: Diethyl nitrosamine, G. Mangostana extract, Ornithine decarboxylase, Hepatocellularcarcinoma.
\end{abstract}

\section{INTRODUCTION}

Hepatocellular carcinoma (HCC) holds the second place in cancer mortality cause in the world population. ${ }^{1}$ HCC is the most common liver cancer and among the most fatal and prevalent malignancies in humans. Ornithine decarboxylase (ODC) is the first rate-limiting enzyme in the polyamine biosynthesis pathway in mammals and its intracellular concentration is tightly controlled. ODC activity is induced in response to cell growth stimuli and is highly expressed in diseases such as inflammation and cancer. ${ }^{2}$ Apoptotic cell death is documented as a critical event in chemical-induced hepatocyte cell death and development of HCC. ${ }^{3}$ In hepatocarcinogenesis several Bcl-2 family members have been implicated along with coupling apoptosis regulation and cell proliferation in distinctive ways. ${ }^{4,5}$ Considering the narrow treatment options and prognosis of HCC, chemoprevention has considered being the best approach in lowering the morbidity and death associated with HCC. Epidemiologic evidence has exposed the chemo preventive effect of the many medicinal plants and their phytochemicals in the prevention of the cancer disease.

HCC can be triggered in experimental animal models using a solitary postnatal shot of the chemical carcinogen diethyl nitrosamine (DEN). ${ }^{6}$ DEN induces chromosomal aberrations, micronuclei and chromatid exchanges in the liver and these mutations are responsible for the gradual events of carcinoma such as lysosomal enzymes changes and ornithine decarboxylase activity. ${ }^{7}$ The rat model of DEN induced carcinoma is the foremost accepted and widely used experimental model to study the chemo preventive and chemotherapeutic potential of many drugs.

The Garcinia mangostana Linn. (mangosteen) is a tropical fruit native of Southeast Asia and reported to contain more health promoting properties. It reduces the risk of many human ailments such as dysentery, eczema and skin related problems due to the presence of polyphenols, xanthones and other important bioprotective constituents. They play a very important role in the protection of liver, intestine, bone and cartilage functions. ${ }^{8,9}$ The bioactive compounds of the mangosteen showed anticancer property against colon preneoplastic lesions, human leukemia, hepatoma, breast, lung and gastric carcinomas cells. ${ }^{10}$

The previous study in our laboratory proved the anticancer efficacy of Garcinia mangostana extract (GME) against DEN induced hepatocellular carcinoma in rats. ${ }^{11}$ This study served as the background for our current research work. Therefore, the study was to evaluate the potential role of GME on hepatocellular cancer in rats to monitor the lysosomal enzymes, cell proliferation, apoptotic proteins and ornithine decarboxylase activities in liver tissues. 


\section{MATERIALS AND METHODS}

\section{Test drug and chemicals}

G. mangostana pericarp extracts powder was obtained from Avasthagen Company, California, USA as a compliment and was applied for the present investigation. All other chemicals used were of analytical grade.

\section{Animals}

Specific and pathogen free Wistar strain rats were chosen for this study. They were obtained and acclimatized to laboratory environment. They were housed in polypropylene cages with stainless steel grid covers and bedding material used is paddy or wheat husk. They were groomed in a controlled environment with feed and drinking water provided in polypropylene bottles. Experimental protocols were approved by Institutional Animal Ethics Committee (IAEC), which follows the guidelines of CPSCEA (Committee for the purpose of control and supervision of experiment on Animals) and the Guide for the care and use of laboratory animals. The IAEC approval number for this study was: Biochem: 005/2008 \& 01/003/10.

\section{Test compound and dose administration levels}

As the toxicity of the plant Garcinia mangostana Linn. was determined in earlier studies, the drug dose was chosen accordingly. Four groups of 6 rats each were used for the study. Group I-Normal rats received distilled water $(1 \mathrm{ml} / \mathrm{kg}$ b.wt); Group II: Rats induced with diethyl nitrosamine (DEN) (0.01\% DEN through drinking water upto 16 weeks); Group III: Rats induced with DEN (0.01\% DEN through drinking water up to 16 weeks and cotreated with GME orally $(400 \mathrm{mg} / \mathrm{kg} \mathrm{wt}) .{ }^{11}$ Group IV: Rats treated with GME ( $400 \mathrm{mg} / \mathrm{kg}$ wt) alone. Food and water were accessible ad libitum. Animals were sacrificed after 16 weeks and livers were dissected and then excised samples of lobes were used for further estimations. Extraction of the target enzymes from liver tissue: $300 \mathrm{mg}$ of liver tissue was homogenized with $6 \mathrm{ml}$ ice-cold distilled water as described elsewhere. ${ }^{12}$ Total protein was determined in each enzyme substrate prior to enzyme assessment, by the method Lowry et al. ${ }^{13}$

\section{Biochemical analyses}

Lysosomal enzymes such as Alpha-L-fucosidase ${ }^{14}$ and beta-Dglucosidase ${ }^{15}$ were measured using previously described method. ODC activity was determined using $0.4 \mathrm{ml}$ hepatocellular $105,000 \times \mathrm{g}$ supernatant fraction per assay tube by measuring release of $14 \mathrm{CO}_{2}$ from DL-[14C] ornithine by the method of Athar et al. ${ }^{16}$

\section{$\mathrm{H}^{3}$ thymidine incorporation}

$\mathrm{H}^{3}$ thymidine incorporation study was done using tissue homogenate, $20 \mu \mathrm{l}$ of the same was taken and $0.5 \mu \mathrm{Ci}$ of $\mathrm{H} 3$-thymidine per well was added. After 4 hours of incubation, the medium was removed, and cell pellets were washed twice with cold $0.05 \mathrm{M}$ Tris- $\mathrm{HCl}$ and $5 \%$ trichloroacetic acid, scrapped and transferred to scintillation cocktail. The level of incorporated $\mathrm{H}^{3}$-thymidine was assessed using Beckman liquid scintillation counter.

\section{Estimation of $\mathrm{Bcl}-\mathrm{xl}, \mathrm{Bax} \& \mathrm{Bcl}-2$}

The quantification of $\mathrm{Bcl}-\mathrm{xl}, \mathrm{Bax}$ and $\mathrm{Bcl}-2$ protein in liver tissue was done by ELISA-based method, as previously validated by Barrow et al. ${ }^{17}$ First, 96-well microplates were coated with $\mathrm{Bcl}-2$ mouse antibody (diluted 1:200 in pH 9.6 bicarbonate buffers, Santa Cruz) and incubated at $4^{\circ} \mathrm{C}$ overnight. Plates were then blocked with $1 \%$ Blotto non-fat dry milk in pH 7.2 PBS at RT for $1 \mathrm{hr}$ and rinsed in PBS 3 times. The normalized mitochondrial samples were then added to the wells, and the microplates were incubated with $\mathrm{Bcl}-\mathrm{xl}$ antibody at $4^{\circ} \mathrm{C}$ for a second night. The plates were again rinsed 3 times in PBS, Bax rabbit IgG antibody (diluted 1:200 in PBS, Santa Cruz) was added to the wells, and the plates were again incubated overnight at $4^{\circ} \mathrm{C}$. After washing again with PBS 3 times, the anti-rabbit secondary antibody conjugated to alkaline phosphatase (diluted 1:1000 in PBS) was added to the wells, which were incubated at $4^{\circ} \mathrm{C}$ for the fourth and final night. The wells were then rinsed with TBS to ensure inorganic phosphate could not inhibit alkaline phosphatase. Then, p-nitrophenyl phosphate, a phosphatase substrate, was dissolved in $\mathrm{pH} 10.4$ glycine buffer $(2 \mathrm{mg} /$ $\mathrm{ml}$ ) with $1 \mathrm{mM} \mathrm{ZnCl}$ and was added to the wells. The microplates were then incubated in the dark for $30 \mathrm{~min}$ at RT and absorbance was read at $415 \mathrm{~nm}$ using a BioRad microplate reader.

\section{Statistical analysis}

Results were expressed as mean \pm S.E.M. Statistical significance was determined by one-way analysis of variance (ANOVA) and post hoc least-significant difference test. $\mathrm{P}$ values less than 0.05 was considered significant.

\section{RESULTS}

\section{Effect of GME on lysosomal enzymes}

The alpha-L-fucosidase and beta-D-glucosidase activities were increased in DEN induced liver tissue. GME treatment markedly decreased its level when compared with the DEN induced hepatocellular tissue. DEN and GME (400mg/kg b.wt) co-treated liver tissue decreased the lysosomal enzyme levels when compared with the respective DEN induced group (Figure 1).

\section{Effect of GME on Ornithine decarboxylase and $\mathrm{H}^{3}$ thymidine assay}

A significant $\left({ }^{* * *} \mathrm{P}<0.001\right)$ increase in ornithine decarboxylase level and $\mathrm{H}^{3}$ thymidine incorporation were evaluated in DEN administered rats (Group II) which indicates cell proliferation, inflammation and cancer when compared with those in control rats (Group I) in which it was not detected. The DEN induced alterations in the enzyme levels DEN were significantly ( $\left.{ }^{\mathrm{a}} \mathrm{P}<0.001\right)$ suppressed in GME treated rats (Figures $2 \& 3$ ).

\section{Effect of GME on apoptotic proteins}

The levels of pro apoptotic and antiapoptotic proteins were analysed in control and experimental rats (Figure 4). Upon DEN induction the apoptotic protein $\mathrm{Bax}$ was downregulated and antiapoptotic proteins $\mathrm{Bcl}-2$ and $\mathrm{Bcl}-\mathrm{xl}$ was significantly $\left({ }^{*} \mathrm{P}<0.001\right)$ upregulated. Administration with GME ( $400 \mathrm{mg} / \mathrm{kg}$ b.wt) induced apoptosis yet after the induction of DEN with increasing Bax and decreasing Bcl-2 and Bcl-xl expressions.

\section{DISCUSSION}

Dysregulation of apoptosis is a vital reason for HCC progression, initiation of tumour; metastasis and maintenance normally are mediated by changes in apoptosis-related proteins. ${ }^{18}$ Some herbal extracts could ameliorate anticancer-induced lysosomal abnormalities, conserving lysosomal integrity, probably, through an antioxidant mechanism. The synthesis of proteins by the tumour with consequent increased fucose turn over. ${ }^{19}$ Alpha-L-fucoidase, lysosomal enzyme remains a gold standard hepatoma marker. The autophagy-lysosomal pathway is involved in the turnover of damaged organelles and misfolded proteins. ${ }^{20}$ Because of this role of autophagy in cell homeostasis and its relationship with apoptosis, we assessed the levels of lysosomal enzymes such as beta-D-glucosidase during DEN induction and upon GME treatment. In this study the levels of lysosomal enzymes was increased during DEN induction, indicating the autophagy mechanism favouring tumour promotion and oncogenesis. On treatment with GME the levels of lysosomal enzymes decreased indicating protective effect of GME on liver cancer. Even though the crosstalk between 


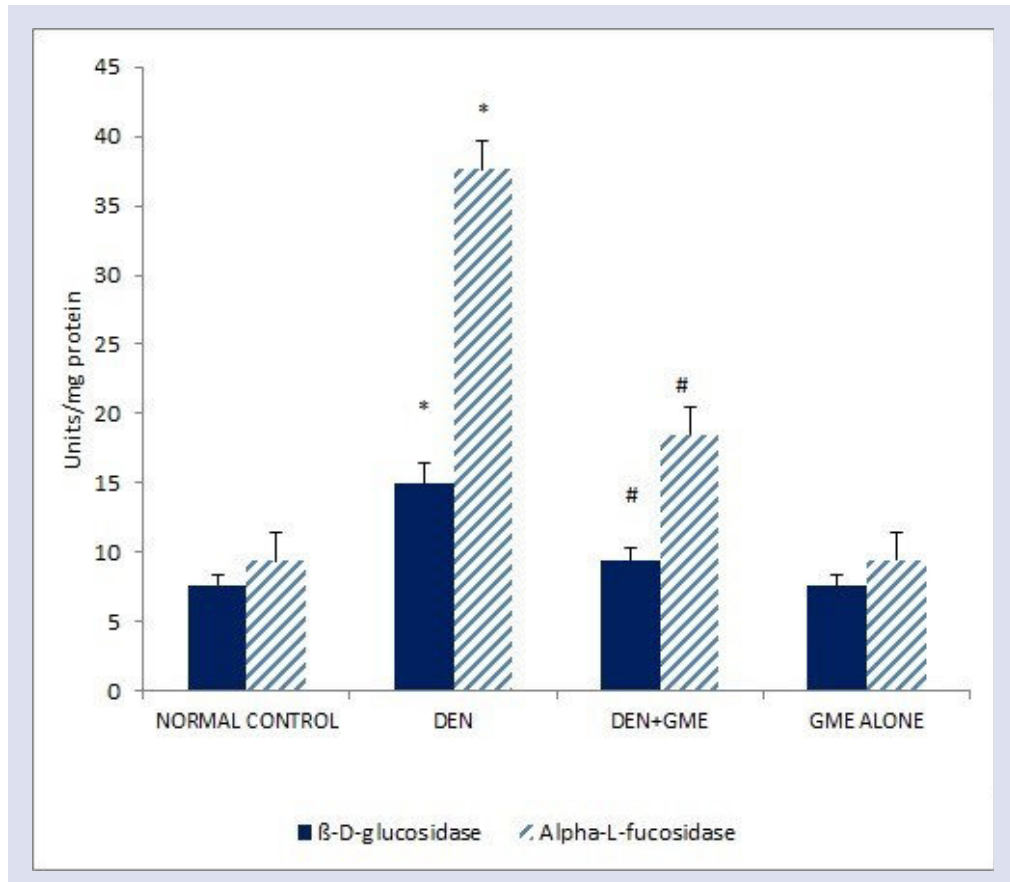

Figure 1: Effect of G. mangostana extract on lysosomal enzymes activities in hepatocellular carcinoma tissues.

Results are expressed as mean \pm S.E.M, $n=6 .^{*} \mathrm{P}<0.001$, statistically significant as compared with control rats and ${ }^{\#} \mathrm{P}<0.001$ statistically significant as compared with DEN control group.

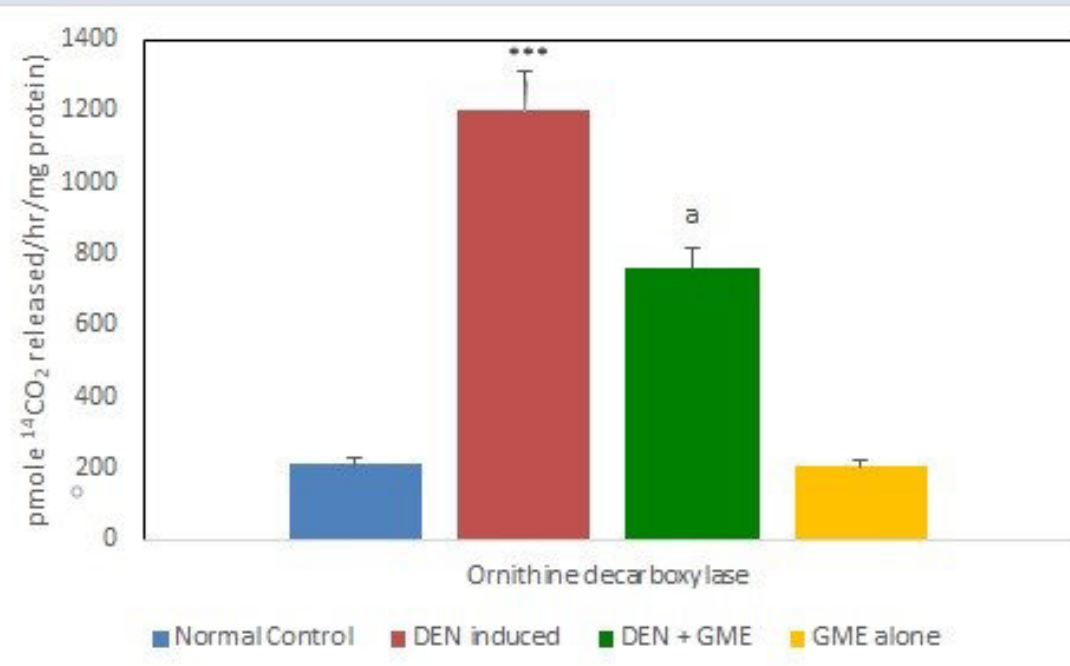

Figure 2: Effect of G. mangostana extract on ornithine decarboxylase activity in hepatocellular carcinoma induced rats.

Results are expressed as mean \pm S.E.M, $n=6 .{ }^{* * * P}<0.001$, statistically significant as compared with control rats and ${ }^{\mathrm{P}}<0.001$ statistically significant as compared with DEN treated rats. 


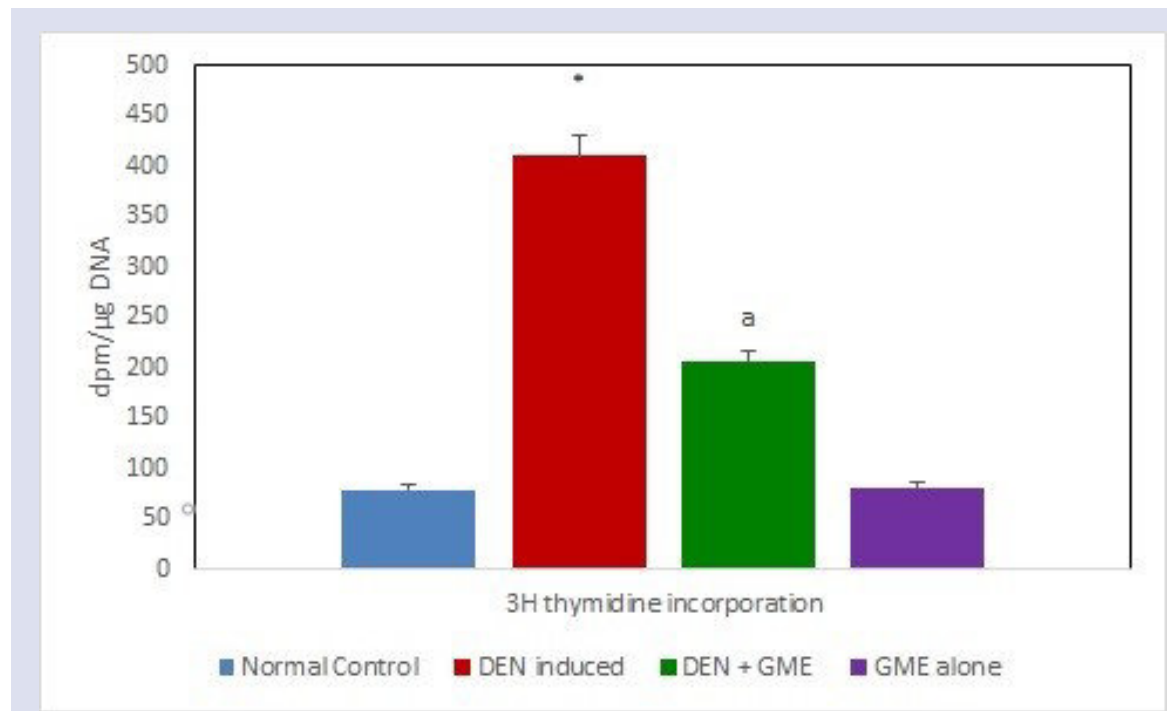

Figure 3: Effect of G. mangostana extract on ${ }^{3} \mathrm{H}$ thymidine incorporation in hepatocellular carcinoma tissues.

Results are expressed as mean \pm S.E.M, $n=6 .^{*} P<0.001$, statistically significant as compared with control rats and $\mathrm{a}<0.001$ statistically significant as compared with DEN treated rats.

autophagy and apoptosis is not well defined, a relationship has been established due to the interaction of different autophagy and apoptosisrelated proteins. ${ }^{21,22}$

ODC is considered to be a possible oncogene because over-expression of ODC can transform mammalian cell lines ${ }^{23}$, indicating that ODC is a biomarker and a potential target for cancer therapy. In the present study, we investigated the functions of ODC on GME treatment during HCC development. Our data showed that ODC levels was higher in HCC tissues and on treatment with GME decreased ODC activity was seen, indicating that GME might be a promising target for HCC therapy by modulating the ODC activity.

To explain the basis of ODC as a tumor promoter in HCC progression, we examined apoptosis in HCC. Our results showed that down regulation of ODC expression with GME treatment significantly increased total apoptosis in HCC tissues. Impairment of apoptosis plays a central role in development of cancer and limits the efficacy of conventional cytotoxic therapies. The Bcl-2 family members are a group of proteins playing a central role in apoptosis, because they form the interface between two events. The Bcl-2 family is divided into 2 subfamilies: anti-apoptotic proteins (e.g.Bcl-2, Bcl-xL) and pro-apoptotic proteins (Bax, Bak, and Bok).The early signalling event engages the cells towards apoptotic process, and the later event conferring their apoptotic characteristics to the cells and elimination by the immune system. ${ }^{24}$

A substantial number of cells escape from apoptosis through up-regulation of these antiapoptotic proteins $\mathrm{Bcl}-2$ and $\mathrm{Bcl}-\mathrm{xL}$ expression. ${ }^{25}$ The balances between $\mathrm{Bcl}-2$ to $\mathrm{Bax}$ as opposed to the levels of the individual proteins are thought to be basic in deciding cell survival or termination. ${ }^{26} \mathrm{~A}$ reduced $\mathrm{Bcl}-2 / \mathrm{Bax}$ proportion will promote apoptosis. ${ }^{27}$ In the present study, polyamine depletion by DEN 
induction downregulated the Bax along with upregulation of Bcl-2 and $\mathrm{Bcl}$-xl. On treatment with GME enhanced the expression levels of Bax and at the same time, the expression of $\mathrm{Bcl}-2$ and $\mathrm{Bcl}-\mathrm{xl}$ was decreased with GME treatment. Our results confirmed that GME by inhibiting polyamine synthesis in HCC resulted in cell death due to apoptosis.

The rate of synthesis of DNA was measured using $\mathrm{H}^{3}$-thymidine incorporation assay. GME decreases $\mathrm{H}^{3}$-thymidine incorporation in DEN induced group which revealed that GME significantly inhibited cell proliferation and promoted apoptosis. The overall mechanism in this study was, in DEN induction there was an increased inflammation and ROS release which had increased ODC levels initiating cellular proliferation which was proved by thymidine incorporation assay, increased antiapoptotic molecules and increased lysosomal enzymes. Previous study was conducted using the DEN carcinogen to enlighten the hepatoprotective effect of pericarp extract of Garcinia mangostana Linn in combating the toxins mediated in the biomedical alterations in rats by carcinogen. ${ }^{11,28}$ GME effectively decreased the proliferation by creating apoptotic environment which was supported by increased apoptotic proteins with decreased ODC, thymidine incorporation and lysosomal enzymes proving GME have an effective apoptotic inducing property confirming GME is an anticarcinogenic drug which could be using in promising treatment of HCC.

\section{CONCLUSIONS}

The improvement of ODC, lysosomal enzyme activity and the enlistment of apoptosis were fundamental to the chemotherapeutic impact of GME. Understanding that there are no successful treatment measures for HCC, our outcomes recommend the potential utilization of mangosteen in chemoprevention of HCC.

\section{CONFLICTS OF INTEREST}

The author's declare that no conflicts of interest.

\section{REFERENCES}

1. Jemal A, Bray F, Center MM. Global cancer statistics. CA Cancer J Clin. 2011;61(2):69-90.

2. Farazi PA, DePinho RA. Hepatocellular carcinoma pathogenesis: from genes to environment. Nat Rev Cancer. 2006;6(9):674-87.

3. Schattenberg JM, Schuchmann M, Galle PR. Cell death and hepatocarcinogenesis: dysregulation of apoptosis signaling pathways. J Gastroenterol Hepatol. 2011;26;1:213-9.

4. Oiu W, Wang X, Leibowitz B, Yang W, Zhang L, Yu J. PUMA-mediated apoptosis drives chemical hepatocarcinogenesis in mice. Hepatology. 2011;54(4):124958.

5. Wree A, Johnson CD, Font-Burgada J, Eguchi A, Povero D, Karin M, et al., Hepatocyte-specific Bid depletion reduces tumor development by suppressing inflammation-related compensatory proliferation. Cell Death Differ. 2015;22(12):1985-94.

6. Newell P, Villanueva A, Friedman SL, Koike K, Llovet JM. Experimental models of hepatocellular carcinoma. J Hepatol. 2008;48(5):858-79.

7. Sivaramakrishnan V, Shilpa PN, Praveen Kumar VR, Niranjali Devaraj S. Attenuation of N-nitrosodiethylamine-induced hepatocellular carcinogenesis by a novel flavonol-Morin. Chem Biol Interact. 2008;171(1):79-88.

8. Pedraza-Chaverri J, Cárdenas-Rodríguez N, Orozco-lbarra M, Pérez-Rojas JM. Medicinal properties of mangosteen (Garcinia mangostana). Food Chem Toxicol. 2008;46(10):3227-39.
9. Yu L, Zhao M, Yang B, Zhao Q, Jiang Y. Phenolics from hull of Garcinia mangostana fruit and their antioxidant activities. Food Chem. 2007;104:176-81.

10. Nabandith V, Suzui M, Morioka T, Kaneshiro T, Kinjo T, Matsumoto K, et al., Inhibitory effects of crude alpha-mangostin, a xanthone derivative, on two different categories of colon preneoplastic lesions induced by 1, 2-dimethylhydrazine in the rat. Asian Pac J Cancer Prev. 2004;5(4):433-8.

11. Vishnu Priya V, Krishna Mohan S, Mallika J Chandra Sada Gopan VS. Ameliorating effects of Garcinia mangostana Linn pericarp extract on hepatocellular antioxidants in Diethyl nitrosamine (DEN) induced Hepatocellular Carcinoma (HCC). Ind J Pharm Edu Res. 2015;49(4):329-37.

12. Kumar S, Sharma JG, Chakrabarti R. Quantitative estimation of proteolytic enzyme and ultrastructural study of anterior part of intestine of Indian major carp (Catla catla) larvae during ontogenesis. Curr Sci. 2000;79(7):1007-11.

13. Lowry OH, Rosebrough NJ, Farr AL, Randall RJ. Protein measurement with the Folin phenol reagent. J Biol Chem. 1951;193(1):265-75.

14. Ayude D, Fernandez-Rodrıguez J, Rodrıguez-Berrocal FJ, Martınez-Zorzano VS, de Carlos A, Gil E, Paez dela Cadena M. Value of the serum $\alpha$-L-fucosidase activity in the diagnosis of colorectal cancer. Oncology. 2000;59(4):310-6.

15. Arnaldos T, Serrano M, Calderon A, Munoz R. A rapid and continuous spectrophotometric method to measure $\beta$-glucosidase activity based on p-nitrophenyl$\beta$-O-D-glucopyranoside hydrolysis. Phytochem Anal. 1999;10(2):171-4.

16. Athar M, Craig E. Targeting ornithine decarboxylase for the prevention of nonmelanoma skin cancer in humans. Cancer Prev Res. 2010;3(1):8-11.

17. Barrow Heaton M, Siler-Marsiglio K, Paiva M, Kotler A, Rogozinski J, et al., Ethanol influences on bax associations with mitochondrial membrane proteins in neonatal rat cerebellum. Neurobiol. 2013;73(2):127-41.

18. Fabregat I. Dysregulation of apoptosis in hepatocellular carcinoma cells. W J Gastroenterol. 2009;15(5):513-20.

19. Murray RK, Granner DKA, Mayes P, Rodwell VW. Harper's Biochemistry. San Mateo, California, USA: Appleton and Lange. Cell diseases resulting from faulty targeting of lysosomal enzymes and genetic deficiencies of glycoprotein lysosomal hydrolases cause diseases such as mannosidosis.1999: p. 691-3.

20. Holmes $\mathrm{EH}$, HakomoriSI. Isolation and characterisation of a new fucoganglioside accumulated in precancerous rat liver and in rat hepatoma induced by N-2-acetylaminofluorine. J Biol Chem. 1982;257(3):769-73.

21. Jiang $H$, White Ej, Rios-Vicil C. Human adenovirus type 5 induces cell lysis through autophagy and autophagy-triggered caspase activity. J Virol. 2011;85(10):4720-9.

22. Wirawan E, Vande Walle L, Kersse K. Caspase-mediated cleavage of Beclin-1 inactivates Beclin-1-induced autophagy and enhances apoptosis by promoting the release of proapoptotic factors from mitochondria. Cell Death Dis. 2010;1(1):18-26.

23. Auvinen M. Human ornithine decarboxylase-overproducing NIH3T3 cellsinduce rapidly growing highly vascularized tumors in nude mice. Cancer Res. 1997;57(14):3016-25

24. Adams JM, Cory S. The Bcl-2 apoptotic switch in cancer development and therapy. Oncogene. 2007;26(9):1324-37.

25. Danial NN, Korsmeyer SJ. Cell death: critical control points. Cell. 2004;116(2):205-19.

26. Fukamachi $Y$, Karasaki $Y$, Sugiura T. Zinc suppresses apoptosis of U937 cells induced by hydrogen peroxide through an increase of the Bcl-2/Bax ratio. Biochem Biophys Res Commun. 1998;246:364-9.

27. Gardner CR. Anticancer drug development based on modulation of the $\mathrm{Bcl}-2$ family core apoptosis mechanism. Expert Rev Anticancer Ther. 2004;4(6):115777.

28. Vishnu Priya V, Mallika Jainu, Surapaneni Krishna Mohan, Karthik B, Saraswathi P, Chandra Sada Gopan V. Toxicity Study of Garcinia Mangostana Linn. Pericarp Extract in Rats. Asian J Exp Biol Sci. 2010;1(3):633-7.

29. Vishnu Priya V, Krishna Mohan S, Mallika Jainu. Biochemical Evidence for the Antitumor Potential of Garcinia mangostana Linn. On Diethylnitrosamine-Induced Hepatocellular Carcinoma. Pharmacog Mag. 2018;14(54):186-90. 


\section{GRAPHICAL ABSTRACT}

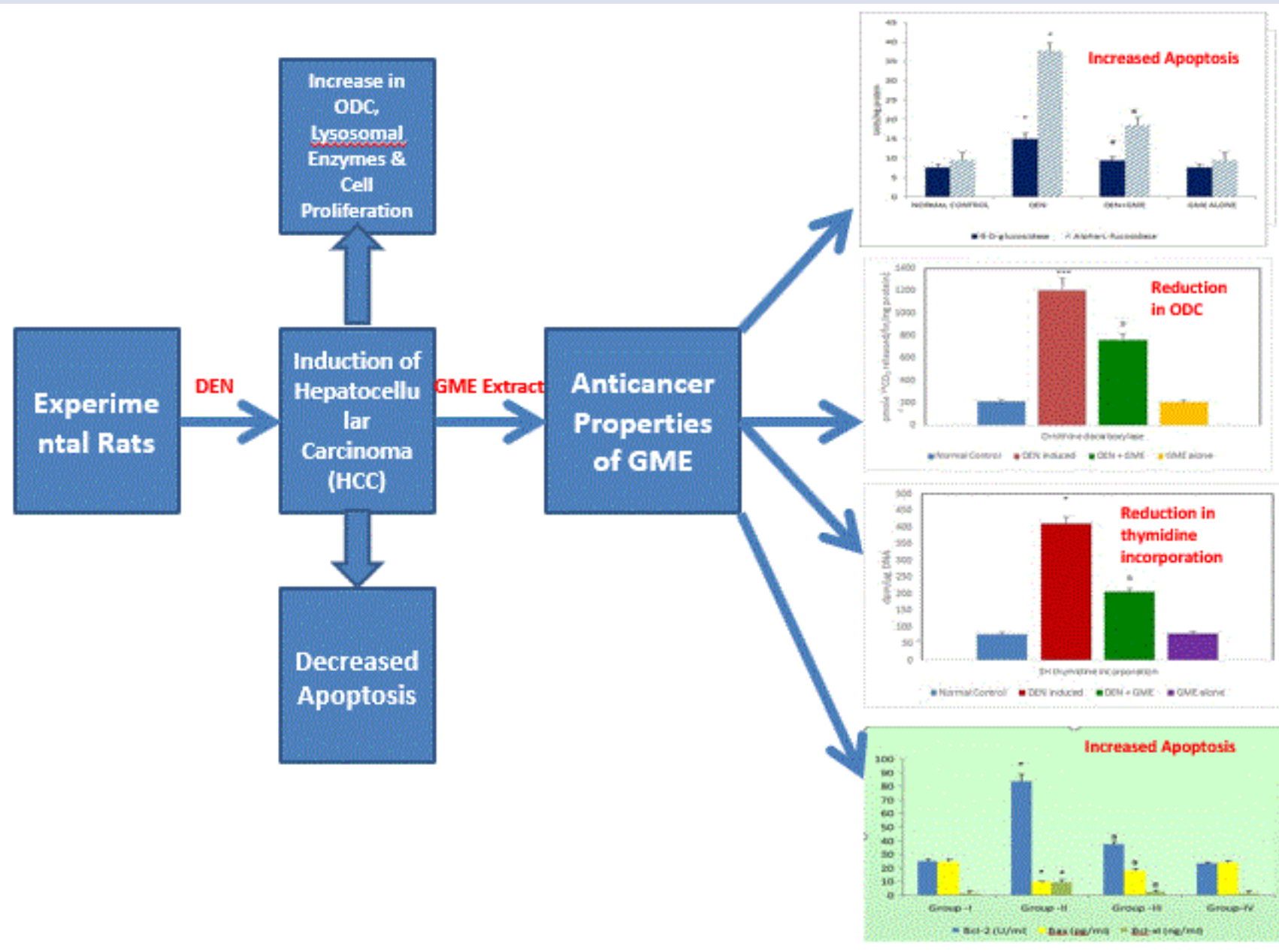

Cite this article: Priya WV, Hussain S, Balakrishna JP, Gayathri R, Mohan SK. Chemopreventive Action of Garcinia Mangostana Linn. on Hepatic Carcinoma by Modulating Ornithine Decarboxylase Activity. Pharmacogn J. 2020;12(6):1383-8. 